\title{
Energy and nitrogen partitioning in dairy cows at low or high metabolizable protein levels is affected differently by postrumen glucogenic and lipogenic substrates
}

\author{
K. Nichols, ${ }^{1,2 *}$ J. Dijkstra, ${ }^{1}$ H. van Laar, ${ }^{3}$ S. Pacheco, ${ }^{4}$ H. J. van Valenberg, ${ }^{4}$ and A. Bannink ${ }^{2}$ \\ ${ }_{1}^{1}$ Animal Nutrition Group, Wageningen University and Research, PO Box 338, 6700 AH Wageningen, the Netherlands \\ ${ }^{2}$ Wageningen Livestock Research, Wageningen University and Research, PO Box 338, 6700 AH Wageningen, the Netherlands \\ ${ }^{3}$ Trouw Nutrition R\&D, PO Box 220, 5830 AE Boxmeer, the Netherlands \\ ${ }^{4}$ Dairy Science and Technology Group of Food Quality and Design, Wageningen University and Research, PO Box 17, $6700 \mathrm{AH}$ Wageningen, \\ the Netherlands
}

\section{ABSTRACT}

This study tested the effects of energy from glucogenic (glucose; GG) or lipogenic (palm olein; LG) substrates at low (LMP) and high (HMP) metabolizable protein levels on whole-body energy and $\mathrm{N}$ partitioning of dairy cattle. Six rumen-fistulated, second-lactation HolsteinFriesian dairy cows (97 $\pm 13 \mathrm{~d}$ in milk) were randomly assigned to a $6 \times 6$ Latin square design in which each experimental period consisted of $5 \mathrm{~d}$ of continuous abomasal infusion followed by $2 \mathrm{~d}$ of rest. A total mixed ration consisting of $42 \%$ corn silage, $31 \%$ grass silage, and $27 \%$ concentrate (dry matter basis) was formulated to meet 100 and $83 \%$ of net energy and metabolizable protein requirements, respectively, and was fed at $90 \%$ of ad libitum intake by individual cow. Abomasal infusion treatments were saline (LMP-C), isoenergetic infusions (digestible energy basis) of 1,319 $\mathrm{g} / \mathrm{d}$ of glucose (LMP-GG), $676 \mathrm{~g} / \mathrm{d}$ of palm olein (LMP-LG; major fatty acid constituents are palmitic, oleic, and linoleic acid), or $844 \mathrm{~g} / \mathrm{d}$ of essential AA (HMP-C), or isoenergetic infusions of $1,319 \mathrm{~g} / \mathrm{d}$ of glucose $+844 \mathrm{~g} / \mathrm{d}$ of essential AA (HMP-GG) or $676 \mathrm{~g} / \mathrm{d}$ of palm olein + $844 \mathrm{~g} / \mathrm{d}$ of essential AA (HMP-LG). The experiment was conducted in climate respiration chambers to determine energy and $\mathrm{N}$ balance in conjunction with milk production and composition, nutrient digestibility, and plasma constituents. Infusion of GG and LG decreased dry matter intake, but total gross energy intake from the diet plus infusions was not affected by GG or LG. Furthermore, GG or LG did not affect total milk, protein, or lactose yields. Infusing GG or LG at the HMP level did not affect milk production differently than at the LMP level. Infusion of GG stimulated energy retention in body tissue, increased plasma glucose and

Received June 20, 2018.

Accepted September 12, 2018.

*Corresponding author: kelly.nichols@wur.nl insulin concentrations, decreased lipogenic metabolites in plasma, and decreased milk fat yield and milk energy output. Nitrogen intake decreased and milk N efficiency increased in response to $\mathrm{GG}$, and $\mathrm{N}$ retention was not affected. Infusion of LG tended to increase metabolizable energy intake, increased milk fat yield and milk energy output, increased plasma triacylglycerides and long-chain fatty acid concentrations, and had no effect on energy retention. Infusion of LG decreased $\mathrm{N}$ intake but did not affect milk $\mathrm{N}$ efficiency or $\mathrm{N}$ retention. Compared with the LMP level, the HMP level increased dry matter intake, gross and metabolizable energy intake, and total milk, fat, protein, and lactose yields. Milk energy output increased at the HMP level, and protein level did not affect total energy retention. Heat production increased at the HMP level, but only when GG and LG were infused. The HMP level increased N intake, milk $\mathrm{N}$ output, and plasma urea concentration, tended to increase $\mathrm{N}$ retention, and decreased milk $\mathrm{N}$ efficiency. Regardless of protein level, GG promoted energy retention and improved milk $\mathrm{N}$ efficiency, but not through increased milk protein yield. Infusion of LG partitioned extra energy intake into milk and had no effect on milk $\mathrm{N}$ efficiency.

Key words: energy balance, nitrogen balance, glucogenic, lipogenic, milk nitrogen efficiency

\section{INTRODUCTION}

The content and the type of energy and protein in lactating cow diets are important factors influencing nutrient transfer from feed into milk components, and interactions between energy and protein at the postabsorptive level are complex. Importantly, changes in metabolic oxidation of macronutrients driven by net supply or postabsorptive interactions influence substrate supply to the lactating mammary gland. Increasing absorptive AA supply increases milk protein yield, whole-body glucose appearance, and AA catabolism, 
but decreases milk $\mathrm{N}$ efficiency and increases $\mathrm{N}$ excreted in urine (Lapierre et al., 2010; Dijkstra et al., 2013; Arriola Apelo et al., 2014). Nitrogen fed above requirement is associated with energy loss through heat production, mainly arising from energy required for ureagenesis. Martin and Blaxter (1965) estimated that during ammonia and urea infusion, $73 \%$ of heat produced per gram of $\mathrm{N}$ infused $(15.9 \mathrm{~kJ} / \mathrm{g}$ out of a total of $21.8 \mathrm{~kJ} / \mathrm{g}$ ) was associated with urea production from ammonia. Reed et al. (2017) estimated a reduction in digestible energy balance of $14.6 \mathrm{~kJ} / \mathrm{g}$ of $\mathrm{N}$ fed above requirement, and an increase in heat production between 17.2 and $31.7 \mathrm{~kJ} / \mathrm{g}$ of excess $\mathrm{N}$. According to the meta-analysis of Spek et al. (2013a), urinary N excretion ranges from 100 to $400 \mathrm{~g} / \mathrm{d}$. Considering the mean increase in heat production per gram of excess $\mathrm{N}$ from Reed et al. (2017), the energy lost via heat production associated with urinary $\mathrm{N}$ excreted in this range is $7.3 \mathrm{MJ} / \mathrm{d}$. Energy required to process AA and excrete excess $\mathrm{N}$ also varies with the form in which dietary protein is supplied (i.e., rumen-degradable vs. rumenundegradable protein; Reed et al., 2017). Furthermore, formulating diets with EAA-balanced MP in support of maximal mammary gland AA extraction and use for milk protein synthesis can improve postabsorptive $\mathrm{N}$ efficiency and increase milk protein yield (Haque et al., 2012; Arriola Apelo et al., 2014).

Glucogenic nutrients are highly important to intermediary metabolism during ruminant lactation because mammary glucose use is high, but direct glucose absorption from the diet is low. Glucogenic diets fed to cows in early and mid-lactation promote energy storage in the body and decrease milk energy content (van Knegsel et al., 2007a,b; Boerman et al., 2015). These shifts in energy partitioning are also observed when glucose or glucogenic precursors are infused along the digestive tract (Reynolds et al., 2001; Rigout et al., 2002a). Infusions of ruminal propionate or postruminal glucose or starch suggest variable effects of elevated glucose availability on total milk, protein, and lactose yields (Raggio et al., 2006; Rius et al., 2010a; Nichols et al., 2016). However, increasing glucogenic energy at low and high levels of protein supply can improve postabsorptive AA transfer efficiency from the gut to milk protein by reducing AA catabolism across the gut and the splanchnic bed, potentially improving mammary gland supply (Rius et al., 2010b). In combination with high circulating AA levels, glucogenic energy may also support $\mathrm{N}$ retention by stimulating AA partitioning toward extra-mammary tissues (Clark et al., 1977; Nichols et al., 2016; Curtis et al., 2018).

In ruminants, lipogenic nutrients appear from degradation of $\mathrm{OM}$ in the rumen, from dietary fat sources reaching the lower gut, or are derived from endogenous fat reserves. Lipogenic nutrients have the potential to increase metabolizable energy intake (MEI) and milk energy output through the direct transfer of dietary fatty acids (FA) into milk (Hammon et al., 2008; Boerman et al., 2015). The effectiveness of dietary fat supplementation depends on FA chain length and degree of saturation (Pantoja et al., 1996; Bremmer et al., 1998; Harvatine and Allen, 2006a). These factors affect feed intake and digestibility, but can also influence the total yield and profile of FA in milk (Enjalbert et al., 2000). Milk and lactose yields from cows fed lipogenic diets may be equal to or higher than from those fed glucogenic or low-fat diets (Cant et al., 1991; Hammon et al., 2008; Lohrenz et al., 2010), but milk protein yield is usually lower or not affected (Cant et al., 1991; Hammon et al., 2008; Boerman et al., 2015). Lipogenic diets can improve milk $\mathrm{N}$ efficiency (Nichols et al., 2018), but literature characterizing whole-body $\mathrm{N}$ balance in response to lipogenic substrates is scarce (Andrew et al., 1991; Cant et al., 1991).

In the present experiment, glucose and palm olein were abomasally infused to study the effect of postabsorptive supply of glucogenic and lipogenic energy on energy and $\mathrm{N}$ metabolism of dairy cattle. Concomitant infusion of EAA allowed the effects of glucose and palm olein to be compared at a low and high MP level. We hypothesized that glucogenic and lipogenic infusions would stimulate milk production equally but through differences in energy and $\mathrm{N}$ partitioning. We expected infusion of glucose and palm olein to affect energy balance through energy retention (ER) and milk energy output, respectively. With regard to $\mathrm{N}$ balance, we expected that glucose and palm olein infusions would improve milk $\mathrm{N}$ efficiency, but that the effects of glucose might interact with low and high MP levels more than the effects of palm olein.

\section{MATERIALS AND METHODS}

\section{Experimental Design and Respiration Chamber Housing}

The following experimental procedures were conducted under the Dutch Law on Animal Experiments in accordance with European Union Directive 2010/63 (European Commission, 2010). To test the effect of energy from glucogenic (glucose; GG) or lipogenic (palm olein; LG) substrates at low (LMP) and high (HMP) MP levels, 6 rumen-fistulated, second-lactation Holstein-Friesian dairy cows with an average milk production $( \pm \mathrm{SD})$ of $25.9 \pm 2.87 \mathrm{~kg} / \mathrm{d}$ at $97 \pm 13 \mathrm{DIM}$ and $633 \pm 53.9 \mathrm{~kg}$ of BW were randomly assigned to a $6 \times 6$ Latin square design. Each experimental period consisted of $5 \mathrm{~d}$ of continuous abomasal infusion fol- 
lowed by $2 \mathrm{~d}$ of rest (Figure 1). Cows were adapted to the experimental conditions for $19 \mathrm{~d}$ before the first experimental period. For the first $14 \mathrm{~d}$ of adaptation, cows were housed individually in tiestalls for acclimatization to the diet and the restriction in movement. From d 15 of the adaptation period, cows were housed individually in identical climate respiration chambers (CRC) for $5 \mathrm{~d}$ of adaptation before the first experimental period began. Cows were housed in CRC for the entire experiment to facilitate determination of gaseous exchange, energy and $\mathrm{N}$ balance, and apparent total-tract nutrient digestibility (ATTD). Detailed descriptions of the CRC design and gas measurements are given by Heetkamp et al. (2015) and van Gastelen et al. (2015). Briefly, each CRC compartment measured $11.8 \mathrm{~m}^{2}$ and had a volume of $34.5 \mathrm{~m}^{3}$. Relative humidity was maintained at $65 \%$, temperature at $16^{\circ} \mathrm{C}$, and the ventilation rate at $43 \mathrm{~m}^{3} / \mathrm{h}$ inside each compartment. The CRC were designed with thin walls equipped with windows to allow audio and visual contact between cows and minimize the effects of social isolation on behavior and performance. Cows were exposed to 17.5 h of light per d (0530 to $2300 \mathrm{~h}$ ).

Gas concentrations and ventilation rates were corrected for pressure, temperature, and relative humidity to arrive at standard temperature and pressure dew point volumes of inlet and exhaust air. Production of $\mathrm{CO}_{2}$ and $\mathrm{CH}_{4}$ and consumption of $\mathrm{O}_{2}$ inside each compartment were calculated from the difference between inlet and exhaust gas volumes. Gas analysis measurement in this experiment was performed as described by van Gastelen et al. (2015), where 4 CRC compartments shared a single gas analyzer, but with the addition of a second gas analyzer shared by the additional 2 CRC compartments measuring gas in 6-min intervals. Calibration gases were sampled once daily instead of the inlet air. The analyzed and actual values of these calibration gases were used to correct the analyzed gas concentrations from the inlet and exhaust air of the 6 compartments. Before the experiment started, $\mathrm{CO}_{2}$ recovery was checked by releasing known amounts of
$\mathrm{CO}_{2}$ into each compartment and comparing the known values with data from the gas analysis system to calculate the recovery. The recovered amounts of $\mathrm{CO}_{2}$ were between 99 and $101 \%(100.1 \pm 0.37 \%)$. Gas measurements during time points when staff entered the CRC compartments (maximum 30 min for milking, feeding, checking abomasal infusion lines) were discarded from the data analysis. Production of $\mathrm{CO}_{2}$ and $\mathrm{CH}_{4}$ and consumption of $\mathrm{O}_{2}$ was assumed to be linear between the last data point before opening and the first data point after closing the CRC.

\section{Diet, Feeding, and Treatment Infusions}

Cows were fed a TMR consisting of $42 \%$ corn silage, $31 \%$ grass silage, and $27 \%$ concentrate on a DM basis (Table 1), formulated to meet 100 and $83 \%$ of $\mathrm{NE}_{\mathrm{L}}$ and MP requirements (CVB, 2008), respectively, for cows consuming $20 \mathrm{~kg}$ of $\mathrm{DM} / \mathrm{d}$ and producing $30 \mathrm{~kg} / \mathrm{d}$ of milk containing $4.0 \%$ fat and $3.4 \%$ protein. Cows were fed ad libitum for the first $10 \mathrm{~d}$ of the 19-d adaptation period. Intake during the final $5 \mathrm{~d}$ of this $10-\mathrm{d}$ ad libitum intake period was used to calculate a $10 \%$ daily intake restriction for individual cows. From d 11, cows were fed this fixed amount for the remainder of the adaptation and experimental periods described above. Fresh feed was allocated twice daily at 0530 and 1530 $\mathrm{h}$ by manually mixing the roughage and concentrate portions into a TMR for individual cows. The roughage portion (corn silage + grass silage) of the diet was mixed twice weekly and stored at $4^{\circ} \mathrm{C}$ for no longer than $4 \mathrm{~d}$ before feeding. The concentrate contained $0.25 \%$ titanium dioxide as an inert marker for estimation of ATTD. Feed refusals at each feeding time point were collected and weighed to determine daily feed intake. Cows had individual and free access to drinking water throughout the entire experiment. For a $34-\mathrm{h}$ period over $\mathrm{d} 4$ and 5 of each experimental period $(0530 \mathrm{~h}$ on d 4 until $1530 \mathrm{~h}$ on d 5), cows were fed using an automated feeding system that dispensed equal portions of feed every $2 \mathrm{~h}$ to promote metabolic steady-state condi-

\begin{tabular}{|c|c|c|c|c|c|c|}
\hline \multicolumn{7}{|c|}{ Experimental period, $\mathrm{d}$} \\
\hline 1 & 2 & 3 & 4 & 5 & 6 & 7 \\
\hline In] & nñ & ning & wns & nng & & \\
\hline & & \multicolumn{3}{|c|}{ Balance period } & & \\
\hline & & & Gas & & & \\
\hline
\end{tabular}

Figure 1. Design of a single 7-d experimental period. Inf 1 to Inf $5=120-\mathrm{h}$ infusion period beginning at $0900 \mathrm{~h}$ on $\mathrm{d} 1$ and ending at $0900 \mathrm{~h}$ on d 6 of each experimental period. The infusion period was followed by a 48 -h wash-out period. Balance period $=71$-h period of total manure collection with milk and feces samples from $1000 \mathrm{~h}$ on d 3 until $0900 \mathrm{~h}$ on d 6 . Gas production $=48$-h period of gas production and consumption measured from $0800 \mathrm{~h}$ on $\mathrm{d} 4$ until $0800 \mathrm{~h}$ on $\mathrm{d} 6$. 
Table 1. Ingredient composition of TMR and analyzed and calculated chemical composition of ingredients (corn silage, grass silage, and concentrate) and complete TMR (g/kg of DM, unless otherwise noted)

\begin{tabular}{|c|c|c|c|c|}
\hline \multirow[b]{2}{*}{ Item } & \multicolumn{3}{|c|}{ Ingredient } & \multirow[b]{2}{*}{$\mathrm{TMR}^{1}$} \\
\hline & Corn silage & Grass silage & Concentrate $^{2}$ & \\
\hline Inclusion & 420 & 313 & 267 & - \\
\hline \multicolumn{5}{|l|}{ Chemical composition } \\
\hline $\mathrm{DM}, \mathrm{g} / \mathrm{kg}$ & 325 & 484 & 903 & 447 \\
\hline Gross energy, MJ $/ \mathrm{kg}$ of DM & 19.0 & 19.2 & 16.7 & 18.4 \\
\hline Crude ash & 38 & 97 & 121 & 79 \\
\hline $\mathrm{CP}$ & 82 & 162 & 206 & 140 \\
\hline Crude fat & 33 & 35 & 26 & 32 \\
\hline $\mathrm{NDF}$ & 354 & 502 & 309 & 388 \\
\hline $\mathrm{ADF}$ & 197 & 271 & 206 & 223 \\
\hline ADL & 11 & 12 & 6 & 10 \\
\hline Starch & 349 & $\mathrm{NA}^{3}$ & 257 & 217 \\
\hline Sugar & NA & 72 & 27 & 29 \\
\hline $\mathrm{DVE}^{4}$ & 54 & 67 & 125 & 77 \\
\hline $\mathrm{OEB}^{5}$ & -41 & 25 & 63 & 7 \\
\hline $\mathrm{NE}_{\mathrm{L}},{ }^{6} \mathrm{MJ} / \mathrm{kg}$ of DM & 6.82 & 6.61 & 7.68 & 6.99 \\
\hline \multicolumn{5}{|c|}{$\begin{array}{l}1 \text { Values for TMR were calculated based on ration composition and analyzed and calculated values obtained for } \\
\text { roughages and concentrate. }\end{array}$} \\
\hline \multicolumn{5}{|c|}{$\begin{array}{l}{ }^{2} \mathrm{Contained}(\mathrm{g} / \mathrm{kg} \text { of } \mathrm{DM}) \text { : ground corn } 8 \% \mathrm{CP}, 370 ; \text { soy hulls, } 372 \text {; soybean meal } 48 \% \mathrm{CP}, 116 \text {; limestone } 37 \% \\
\mathrm{Ca}, 29 ; \text { formaldehyde-treated soybean meal, } 24 ; \mathrm{MgO} \text {, } 20 \text {; urea, } 20 \text {; monocalcium phosphate, } 20 ; \mathrm{NaCl}, 18 \text {; } \\
\text { trace mineral and vitamin premix, } 10 ; \mathrm{TiO}_{2} \text { was included at } 0.25 \% \text { of concentrate } \mathrm{DM} \text {. } \\
{ }^{3} \mathrm{NA}=\text { not analyzed. }\end{array}$} \\
\hline
\end{tabular}

tions in preparation for the blood sampling protocol described below.

Infusion lines were placed in the abomasum via the rumen cannula $7 \mathrm{~d}$ before the first experimental period and were checked daily for patency and position. The infusion device was constructed from $200 \mathrm{~cm}$ of braided polyvinyl chloride hose $(6.4 \mathrm{~mm}$ i.d., $11.2 \mathrm{~mm}$ o.d.) attached to a rumen cannula plug at the proximal end and a flexible disc (equipped with holes to allow particle and fluid passage) at the distal end to secure its placement through the sulcus omasi. The flexible disc was $12 \mathrm{~cm}$ in diameter and made from plastisol (Bar Diamond Inc., Parma, ID). The infusion line (Tygon S3 E-3606, 3.2 mm i.d., 6.4 mm o.d.; Saint-Gobain Performance Plastics, Courbevoie, France) was connected between the infusate, infusion pump, and the proximal end of the abomasal infusion line with luer-to-tubing connectors (Sigma-Aldrich, St. Louis, MO). Infusion treatments were (1) $0.9 \%$ saline (LMP-C; $90 \% \mathrm{NE}_{\mathrm{L}}$, $75 \%$ MP), (2) 1,319 g/d of glucose (LMP-GG; $100 \%$ $\mathrm{NE}_{\mathrm{L}}, 75 \% \mathrm{MP}$ ), (3) $676 \mathrm{~g} / \mathrm{d}$ of palm olein (LMP-LG; $100 \% \mathrm{NE}_{\mathrm{L}}, 75 \% \mathrm{MP}$ ), (4) $844 \mathrm{~g} / \mathrm{d}$ of EAA (HMP-C; $\left.100 \% \mathrm{NE}_{\mathrm{L}}, 120 \% \mathrm{MP}\right),(5) 1,319 \mathrm{~g} / \mathrm{d}$ of glucose +844 $\mathrm{g} / \mathrm{d}$ of EAA (HMP-GG; $110 \% \mathrm{NE}_{\mathrm{L}}, 120 \% \mathrm{MP}$ ), and (6) $676 \mathrm{~g} / \mathrm{d}$ of palm olein $+844 \mathrm{~g} / \mathrm{d}$ of EAA (HMPLG; $110 \% \mathrm{NE}_{\mathrm{L}}, 120 \% \mathrm{MP}$ ), where $\mathrm{MP}$ and $\mathrm{NE}_{\mathrm{L}}$ reflect the proportion of requirements met by the restricted feeding level of the diet plus the infusate. Treatment solutions were administered in 10-L batches which were replenished daily and infused via multi-channel peristaltic pumps at a rate of $6.95 \mathrm{~mL} / \mathrm{min}$ to facilitate 120 $\mathrm{h}$ of continuous infusion $(0900 \mathrm{~h}$ on d 1 until $0900 \mathrm{~h}$ on d 6 of each experimental period; Figure 1). The EAA infusions delivered EAA in same profile and amount as found in $1.5 \mathrm{~kg}$ of casein according to Metcalf et al. (1996) and at the following rates (g/d): L-Arg (59), L-His (48), L-Ile (86), L-Val (96), L-Leu (141), L-Phe (141), DL-Met (41), L-Lys (147), L-Thr (63), and L-Trp (21). All AA were provided by Ajinomoto Eurolysine (Paris, France) and Ajinomoto Omnichem (Wetteren, Belgium) with the exception of DL-Met, which was provided by Adisseo France (Malicorne, France). As determined by GC of methyl esters, the FA composition of palm olein (weight basis) was $1.2 \%<\mathrm{C} 16,43.3 \% \mathrm{C} 16: 0$, 0.1\% C17:0, 1.0\% C18:0, 42.5\% C18:1 cis-9, $11.0 \%$ C18: 2n-6, 0.8\% >C18:2. Daily 10-L batches of LMP-LG and HMP-LG were split into 5-L batches that were replenished twice daily to facilitate continuous infusion of palm olein, which was evenly mixed with water or with the EAA solution via continuous stirring. Daily infusion dosages (g/d) of LMP-GG, LMP-LG, and HMP-C were designed to be isoenergetic based on the gross energy (GE) content of the EAA infusion, which was calculated to be $24.3 \mathrm{MJ} / \mathrm{kg}$ based on the heat of combustion of individual EAA in the infusate. Doses $(\mathrm{g} / \mathrm{d})$ of glucose and palm olein were calculated assuming GE 
contents of 15.5 and $37.9 \mathrm{MJ} / \mathrm{kg}$, respectively, and $80 \%$ digestibility of palm olein (Benson et al., 2001; NRC, 2001). Digestibility of EAA and glucose was assumed to be $100 \%$.

\section{Measurements and Sample Collection}

Measurements of $\mathrm{CO}_{2}$ and $\mathrm{CH}_{4}$ production and $\mathrm{O}_{2}$ consumption were based on data recorded from $\mathrm{d} 4$ $(0800 \mathrm{~h})$ through $\mathrm{d} 6(0800 \mathrm{~h})$ of each experimental period, whereas energy and $\mathrm{N}$ balance and ATTD were based on manure and feces collection from d 3 (1000 h) through d 6 (0900 h; balance period; Figure 1). Each CRC compartment was cleaned at $0900 \mathrm{~h}$ on d 3 (taking approximately $60 \mathrm{~min}$ ) to remove all manure collected from the end of the previous period to facilitate a fresh total collection period. At the end of each balance period (which corresponded with the end of the infusion period), cows were weighed and the manure from each compartment produced during the 71-h balance period was separately and quantitatively collected, weighed, and mixed. Manure samples were collected and stored at $-20^{\circ} \mathrm{C}$ until analysis. In addition, to quantify contribution of $\mathrm{N}$ from volatilized ammonia appearing from the mixing of urine and feces in manure, samples of condensed water from the chamber heat exchanger and from $25 \%$ sulfuric acid solution (wt/wt), through which outflowing air was led to trap aerial ammonia, were collected from each CRC compartment. These samples were stored at $4^{\circ} \mathrm{C}$ until analysis. During the balance period, feces was collected by rectal grab sampling at 0530 and $1530 \mathrm{~h}$ (6 samples) and immediately pooled into a composite sample by cow, which was stored at $-20^{\circ} \mathrm{C}$ until analysis. Feed refusals, when present, were collected during the balance period and stored at $4^{\circ} \mathrm{C}$. After each balance period they were pooled by cow, sampled, and stored at $-20^{\circ} \mathrm{C}$ until analysis.

Cows were milked twice daily at 0530 and $1530 \mathrm{~h}$ during the adaptation and experimental periods. Milk weight was recorded at each milking, and samples were collected at each milking into tubes containing sodium azide and stored at $4^{\circ} \mathrm{C}$ until analysis within $4 \mathrm{~d}$. Two additional milk samples ( $5 \mathrm{~g} / \mathrm{kg}$ of milk) were collected separately and pooled by cow at each milking during the balance period (6 milkings). One set of samples was stored at $-20^{\circ} \mathrm{C}$ until $\mathrm{GE}$ and $\mathrm{N}$ analyses. The second set of samples was stored at $4^{\circ} \mathrm{C}$ between milkings and finally split into $200-\mathrm{mL}$ aliquots before storing at $-20^{\circ} \mathrm{C}$ pending milk FA analysis. Samples of corn silage, grass silage, and concentrate were collected twice weekly during feed preparation. These samples were pooled per period and stored at $-20^{\circ} \mathrm{C}$ until analysis. On d 5 of each experimental period, blood samples were collected from the coccygeal vessels into $10-\mathrm{mL}$ sodium heparin and potassium EDTA Vacutainers (Becton Dickinson, Rutherford, NJ) at 0730, 0930, 1130, 1330, and 1530 h. After each sampling point, collection tubes were immediately placed in ice and centrifuged at $3,000 \times g$ for $15 \mathrm{~min}$ at room temperature. Plasma was pooled over sampling time points by cow and period and stored at $-20^{\circ} \mathrm{C}$ until analysis.

\section{Analytical Procedures}

Samples of corn silage, grass silage, concentrate, manure, and feces were thawed at room temperature, oven-dried at $60^{\circ} \mathrm{C}$ until a constant weight was reached, and ground to pass a 1-mm screen using a Wiley mill (Peppink 100AN, Olst, the Netherlands). Wet chemical analysis for $\mathrm{DM}$, ash, $\mathrm{N}, \mathrm{NH}_{3}$, crude fat, starch, sugars, $\mathrm{NDF}, \mathrm{ADF}, \mathrm{ADL}$, and titanium was performed as described by Nichols et al. (2018). Crude protein content was calculated as total analyzed $\mathrm{N} \times 6.25$. An adiabatic bomb calorimeter (IKA-C700, Janke and Kunkel, Heitersheim, Germany) was used for determination of GE content (ISO 9831; ISO, 1998). Corn silage, grass silage, and concentrate samples were analyzed for DM, ash, N, crude fat, starch (except grass silage), sugars (except corn silage), NDF, ADF, ADL, GE, and titanium (concentrate only). Samples of refused feed were analyzed for DM. Manure samples were analyzed for DM, N, and GE. Feces samples were analyzed for DM, ash, N, crude fat, starch, NDF, GE, and titanium. In addition, samples of condensed water and the sulfuric acid solution were analyzed for N. Reported values for nutrient content of the TMR were calculated from ration composition and analyzed values obtained for the roughage and concentrate. The $\mathrm{NE}_{\mathrm{L}}$ was calculated with the VEM (feed unit lactation) system according to Van Es (1978). For corn silage and grass silage, intestinal digestible protein (DVE; see Table 1), RDP balance (OEB; see Table 1), and $\mathrm{NE}_{\mathrm{L}}$ were calculated based on the chemical composition as obtained by near-infrared spectroscopy analysis (Eurofins Agro, Wageningen, the Netherlands). For the concentrate, DVE, OEB, and $\mathrm{NE}_{\mathrm{L}}$ were calculated based on table values for composition of the ingredients (CVB, 2008). For the TMR, these were calculated from ration composition of all roughage and concentrate ingredients.

Milk samples from the morning and afternoon milkings were analyzed separately for protein, fat, lactose, and urea by mid-infrared spectroscopy (ISO 9622; ISO, 2013; VVB, Doetinchem, the Netherlands). Pooled milk samples were analyzed for $\mathrm{GE}$ and $\mathrm{N}$ in fresh material as described above. Fatty acid composition of pooled milk samples was analyzed by GC as described by Nichols et al. (2018). Blood plasma was analyzed by the Veterinary Diagnostic Laboratory (Utrecht University, 
Utrecht, the Netherlands) as described by van Knegsel et al. (2007b).

\section{Calculations and Statistical Analysis}

Heat production $(\mathrm{kJ} / \mathrm{d})$ was calculated as 16.175 $\times \mathrm{VO}_{2}(\mathrm{~L} / \mathrm{d})+5.021 \times \mathrm{VCO}_{2}(\mathrm{~L} / \mathrm{d})$ where $\mathrm{VO}_{2}$ and $\mathrm{VCO}_{2}$ are volumes of $\mathrm{O}_{2}$ consumed and $\mathrm{CO}_{2}$ produced, respectively (Gerrits et al., 2015). Apparent total-tract digestibility was calculated considering the nutrient inflow from the diet and the treatment infusions. The infusion treatments contributed DM, ash, N, and GE. Dry matter of the infusion ingredients was assumed to be $100 \%$ plus contribution of ash in the saline $(99 \mathrm{~g} / \mathrm{d}$ of $\mathrm{NaCl}$ ) and EAA infusions, and hydroxide from mixing the EAA solutions $(116 \mathrm{~g} / \mathrm{d}$ of $\mathrm{NaOH}$ and $75 \mathrm{~g} / \mathrm{d}$ of $\mathrm{HCl}$ were used to facilitate EAA mixing). Nitrogen content of the EAA infusion was calculated based on the molar weight of $\mathrm{N}$ in individual $\mathrm{EAA}$ in the infusate. Gross energy contributions from the infusates were calculated according to the assumptions described above.

Milk yield, milk composition, and DMI were averaged over the 3-d balance period. Variances in lactation performance, milk FA composition, digestibility, energy and $\mathrm{N}$ balance, and plasma constituents were analyzed using the MIXED procedure of SAS (SAS Institute Inc., Cary, NC). The model contained main and interaction effects of infusion treatment factors (GG, LG, and AA) and period as fixed effects and cow as a random effect. Differences were considered significant at $P \leq 0.050$ and tendencies at $0.050<P \leq 0.100$. Multiple comparisons between treatment means were made using the Tukey-Kramer method when GG $\times$ AA or LG $\times$ AA interactions were detected at $P \leq 0.100$. Treatment arrangement within the Latin square was balanced for first-order carryover effects in subsequent periods (Williams, 1949), as each treatment immediately preceded and followed every other treatment exactly once in each square. We observed no carryover effects between periods, assessed by testing for an effect of the previous treatment in the ANOVA.

\section{RESULTS}

\section{DMI, Milk Production, and Digestibility}

Infusing GG or LG at the HMP level did not affect DMI, milk production, or milk composition differently than at the LMP level (no significant GG $\times$ AA or LG $\times$ AA interactions detected; $P>0.210$; Table 2). Dry matter intake decreased in response to GG and LG $(P$ $\leq 0.015)$ and increased at the HMP level $(P=0.041)$. Total milk yield was unaffected by GG and LG $(P>$
$0.610)$ and increased at the HMP level $(P<0.001)$. Yields of milk protein and lactose were unaffected by GG and LG $(P>0.280)$ and increased at the HMP level $(P<0.001)$. Milk fat yield decreased in response to GG $(P<0.001)$, increased in response to LG $(P<$ $0.001)$, and increased at the HMP level $(P=0.023)$. Infusion of GG and LG had no effect on protein or lactose content, but fat content decreased in response to GG $(P<0.001)$ and increased in response to LG $(P$ $<0.001)$. The HMP level decreased milk fat and lactose content $(P \leq 0.001)$, and increased milk protein content $(P<0.001)$. Fat- and protein-corrected milk yield decreased in response to GG $(P=0.027)$, increased in response to LG $(P=0.021)$, and increased at the HMP level $(P<0.001)$. Milk urea content was unaffected by GG or LG $(P>0.240)$ and increased at the HMP level $(P=0.017)$.

For ATTD, no significant GG $\times$ AA or $\mathrm{LG} \times \mathrm{AA}$ interactions were detected $(P>0.291$; Table 3$)$. Infusion of GG decreased crude fat digestibility $(P<0.001)$ and tended to increase GE digestibility $(P=0.097)$. Infusion of LG increased crude fat digestibility $(P<$ 0.001). The HMP infusion level increased CP and GE digestibility $(P \leq 0.001)$ and tended to increase DM digestibility $(P=0.075)$. Apparent total-tract digestibility of OM, NDF, and starch were unaffected by treatment.

\section{Milk FA Composition}

Infusion of GG increased concentrations of total de novo $(<16 \mathrm{C})$ and mixed $(16 \mathrm{C}) \mathrm{FA}(P<0.001)$ and decreased concentration of preformed $(>16 \mathrm{C})$ FA $(P$ $<0.001$; Table 4) in milk fat. Concentration of total SFA increased $(P<0.001)$, total MUFA decreased $(P$ $<0.001)$, and total PUFA tended to decrease $(P=$ 0.068 ) in response to GG. Individually, all FA $\leq \mathrm{C} 16: 0$ increased or tended to increase in response to GG $(P \leq$ 0.099), with the exception of $\mathrm{C} 4: 0$, iso $\mathrm{C} 15: 0$, and anteiso C15:0, which decreased $(P \leq 0.011)$ and iso C14:0, which was unaffected. The FA C18:3n- 6 increased $(P$ $=0.023)$ in response to GG. In addition, C15:0 was affected and C11:0, C18:3n-6, and C20:0 tended to be affected by a GG $\times$ AA interaction where their concentration increased further when GG was infused at the HMP level compared with the LMP level $(P \leq 0.086)$. The FA 18:1 trans-10 + trans-11 tended to be affected by a GG $\times$ AA interaction where its concentration decreased further when GG was infused at the HMP level compared with the LMP level $(P=0.096)$. Infusion of GG decreased or tended to decrease $(P \leq 0.071)$ concentration of $\mathrm{C} 16: 1$ cis- 9 , C16:1 trans- 9 , C17:0, C17:1 cis-9, C18:0, C18:1 cis-9, C18:1 cis-12, C18:1 cis-13, 
ENERGY TYPE AFFECTS ENERGY AND NITROGEN BALANCE
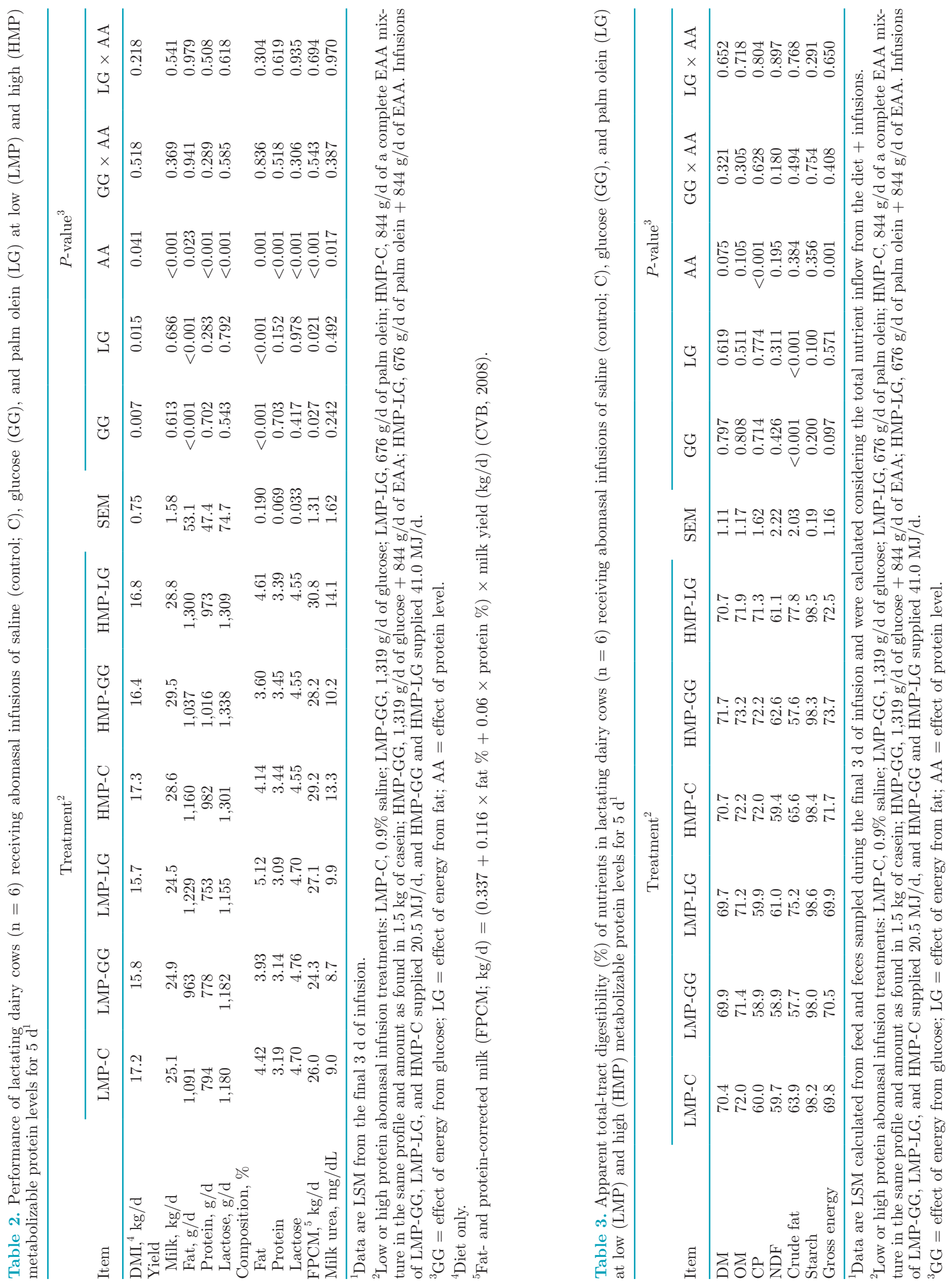
C18:1 trans-15 + C18:1 cis-11, total CLA, C18:3n-3, and $\mathrm{C} 20: 4 \mathrm{n}-6$.

Infusion of LG decreased concentrations of total de novo and mixed FA $(P<0.001)$ and increased concentration of preformed FA $(P<0.001)$ in milk fat. Concentration of total SFA decreased $(P<0.001)$, and concentrations of total MUFA and PUFA increased $(P$ $<0.001)$ in response to LG. Individually, iso C17:0, C18:1 cis-9, C18:1 trans-15 + C18:1 cis-11, C18:2n-6, C18:3n-3, and C20:4n-3 increased or tended to increase in response to LG $(P \leq 0.082)$. Concentrations of all FA $\leq \mathrm{C} 16: 1$ and $\mathrm{C} 17: 0, \mathrm{C} 17: 1$ cis-9, C18:0, C18:1 cis13, C20:0, C20:2n-6, and C20:4n-6 decreased or tended to decrease in response to LG $(P \leq 0.069)$. Total CLA was affected by a $\mathrm{LG} \times \mathrm{AA}$ interaction where its concentration increased when LG was infused at the LMP level but decreased at the HMP level $(P=0.050)$. The n-6 to n-3 ratio increased in response to LG $(P<0.001)$ and was unaffected by GG or protein level.

Infusions at the HMP level increased the concentration of total de novo FA $(P=0.001)$, decreased total mixed FA $(P=0.015)$, and had no effect on total preformed FA, SFA, MUFA, or PUFA concentrations in milk fat. Individually, all FA $\leq \mathrm{C} 12: 0, \mathrm{C} 14: 0, \mathrm{C} 14: 1$ cis-9, C15:0, C18:3n-6, and C20:0 increased $(P \leq 0.033)$ and concentrations of C16:0, C18:0, C18:1 trans-10 + trans-11, C22:5n-3, and C24:0 decreased $(P \leq 0.044)$ at the HMP level.

\section{Energy and N Balance}

Metabolic BW tended $(P=0.071)$ to be greater with HMP than LMP treatments and was not affected by GG or LG infusion (Table 5). Daily $\mathrm{CH}_{4}$ production expressed per unit metabolic BW tended to be affected by a GG $\times$ AA interaction where it decreased with GG but only at the LMP level $(P=0.079)$. The ratio of MEI to gross energy intake (GEI) tended to be affected by a $\mathrm{GG} \times \mathrm{AA}$ interaction where the ratio increased in response to GG infusion at the LMP level, but was unaffected by GG infusion at the HMP level $(P=0.073)$. A GG $\times$ AA interaction also affected heat production where it decreased with GG only at the LMP level $(P=0.027)$. Infusion of GG increased total ER $(P=0.034)$ and decreased milk energy output $(P=$ $0.019)$. Infusion of GG decreased $\mathrm{N}$ intake $(P=0.011)$ and increased milk $\mathrm{N}$ efficiency $(P=0.004)$.

Infusion of LG decreased $\mathrm{CH}_{4}$ production $(P=0.007)$, tended to increase MEI $(P=0.051)$, and increased the MEI:GEI ratio and energy output in milk $(P \leq 0.002)$. A LG $\times$ AA interaction affected heat production where it decreased with LG only at the LMP level $(P=0.007)$. Infusion of LG decreased $\mathrm{N}$ intake $(P=0.023)$ but did not affect other $\mathrm{N}$ balance parameters. 
NICHOLS ET AL.

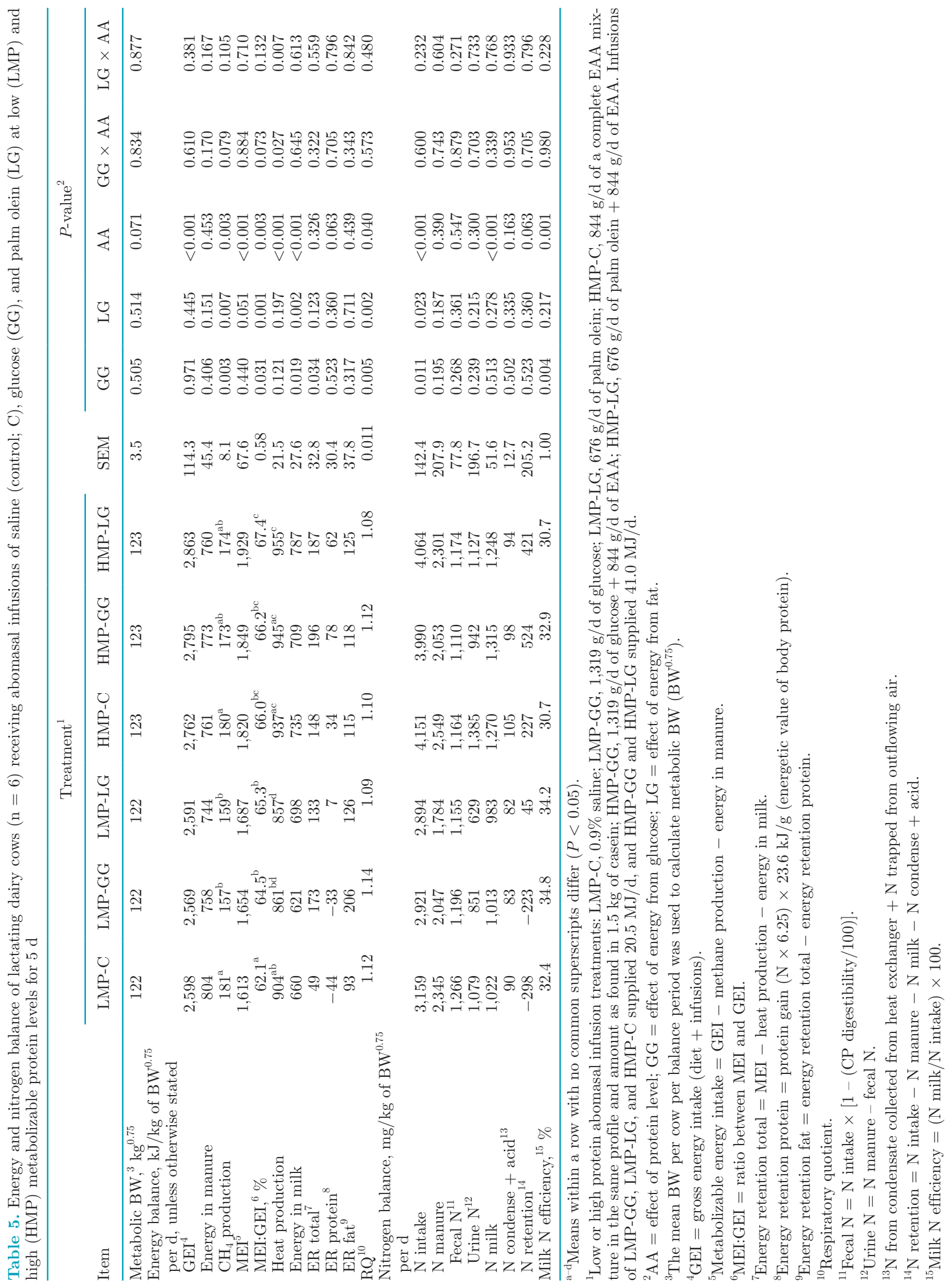


Infusions at the HMP level increased GEI, $\mathrm{CH}_{4}$ production, MEI, the MEI:GEI ratio, heat production, and milk energy output $(P \leq 0.003)$, and tended to increase $\mathrm{ER}$ in protein $(P=0.063)$. The HMP infusion level increased $\mathrm{N}$ intake and milk $\mathrm{N}$ output $(P<0.001)$, tended to increase $\mathrm{N}$ retention $(P=0.063)$, and decreased milk $\mathrm{N}$ efficiency $(P=0.001)$.

The respiratory quotient $(\mathbf{R Q})$ increased in response to GG $(P=0.005)$, decreased in response to LG $(P=$ $0.002)$, and decreased at the HMP level $(P=0.040)$.

\section{Plasma Constituents}

Arterial plasma concentration of glucose and insulin increased in response to GG $(P \leq 0.044$; Table 6$)$ and concentration of $\mathrm{BHB}$, nonesterified fatty acids (NEFA), and long-chain fatty acids (LCFA) decreased $(P \leq 0.030)$. Plasma urea tended to be affected by a $\mathrm{GG} \times$ AA interaction where its concentration decreased with GG only at the HMP level $(P=0.081)$. Infusion of LG increased triacylglyceride (TAG) and LCFA concentrations, and a $\mathrm{LG} \times \mathrm{AA}$ interaction tended to affect plasma urea concentration where LG tended to increase urea concentration at the LMP level, but tended to decrease urea concentration at the HMP level $(P=0.090)$. The HMP infusion level increased plasma $\mathrm{BHB}$ and urea concentrations $(P \leq 0.005)$.

\section{DISCUSSION}

\section{Energy and N Partitioning}

This study tested energy and $\mathrm{N}$ balance in midlactation cows using 5-d abomasal infusions in a Latin square design. The findings of the current study, in particular with regard to energy and $\mathrm{N}$ partitioning, could appear to be relevant to the stage of lactation of the animals or to the duration of the abomasal infusions. First, we can assume these mid-lactation cows were not metabolically challenged with regard to energy balance, as the LMP-C infusion (the control treatment) resulted in positive ER and plasma NEFA concentrations indicative of cows in positive energy balance $(<200 \mu M$; Adewuyi et al., 2005). Second, very short-term studies $(<24 \mathrm{~h})$ in nonruminants have shown increases in protein synthesis in skeletal muscle during glucose and EAA infusions, as well as during insulin clamps (O'Connor et al., 2003; Wilson et al., 2010), and the cellular signaling cascades regulating these responses have been shown to respond within minutes to altered nutritional or hormonal stimuli. With this in mind, infusion periods of $5 \mathrm{~d}$ provide sufficient time to observe mobilization or deposition of energy metabolites and $\mathrm{N}$ from body pools to support a physiological response. 
The responses in milk production, DMI, and energy and $\mathrm{N}$ balance in the current study generally agree with other studies where starch was infused postruminally for 2 wk (Reynolds et al., 2001), and where glucogenic or lipogenic diets were fed for 28 d (Boerman et al., 2015) or for the first $9 \mathrm{wk}$ of lactation (van Knegsel et al., 2007a,b), as discussed below.

Glucogenic Infusion. In contrast to our hypothesis, GG did not increase milk production, likely related to the decrease in DMI. Glucose infusion decreased DMI $0.7 \mathrm{~kg} / \mathrm{d}$ compared with infusions with no $\mathrm{GG}$, but total GEI from the diet plus infusion was not affected and supported the same total milk yield as LMP-C. Similarly, others have achieved equal milk production from control and glucose infusions (1,000 to $1,500 \mathrm{~g} / \mathrm{d}$ ) when maintaining the same level of total $\mathrm{NE}_{\mathrm{L}}$ intake by adjusting DMI allowance (Lemosquet et al., 1997; Hurtaud et al., 1998, 2000). Abomasal infusion of GG increased the proportion of GEI recovered as ME and reduced $\mathrm{CH}_{4}$ production, which can be attributed to lower diet DMI and minor contribution of hindgut fermentation to total enteric $\mathrm{CH}_{4}$ production (Ellis et al., 2008). In line with our hypothesis, GG increased body ER, associated with a $55 \mathrm{~kJ} / \mathrm{kg}$ of $\mathrm{BW}^{0.75}$ per d decrease in milk energy output compared with nonGG infusions, mainly because of a decrease in milk fat content. Arterial concentrations of glucose and insulin increased with GG, in agreement with several studies postruminally infusing glucose (Lemosquet et al., 1997; Rigout et al., 2002b; Nichols et al., 2016) or starch (Rius et al., 2010a). Through elevated circulating glucose concentration and the associated insulin release, 2 mechanisms may be contributing to the decreased DMI and increased energy balance observed with abomasal glucose infusion into mid-lactation cows. First, elevated insulin and glucose concentrations have been independently linked to the downregulation of hepatic gluconeogenesis, which under steady-state feeding conditions and continuous glucose infusion may affect homeostatic control of liver tricarboxylic acid cycle intermediates contributing to regulation of glycemia through reduced feed intake (Lomax et al., 1979; Baird et al., 1980; McGuire et al., 1995). Insulin is also linked to the release of satiety-related gut peptides (Relling and Reynolds, 2007). Second, insulin stimulates lipogenesis in nonmammary tissues (Griinari et al., 1997), playing an important regulatory role in energy balance throughout lactation (Bauman and Elliot, 1983). This metabolic response is characterized by decreased plasma concentrations of acetate, BHB, and NEFA and is often observed when glucose absorption is increased through intake of glucogenic substrates or postruminal infusion of glucose (Rigout et al., 2002a; van Knegsel et al., 2007b; Nichols et al., 2016). Through this re- sponse, glucogenic diets fed to early and mid-lactation cows stimulate ER in body tissue and reduce milk fat synthesis by repartitioning energy-dense milk fat substrates toward adipose (McGuire et al., 1995; Griinari et al., 1997; van Knegsel et al., 2007a). Taken together, increased insulin concentration, decreased concentrations of BHB and NEFA, increased ER, and decreased milk energy output in response to GG support the findings of others who report positive energy balance and decreased milk energy in early and mid-lactation cows fed glucogenic diets (van Knegsel et al., 2007a,b; Boerman et al., 2015).

In line with reduced milk energy output, milk fat yield and concentration decreased in response to GG in agreement with other studies characterizing the effects of postruminal glucose or starch supply (Lemosquet et al., 1997; Hurtaud et al., 2000; Reynolds et al., 2001). Of milk fat produced, concentrations of $\leq 16 \mathrm{C}$ FA and SFA increased and that of preformed FA decreased with GG, which agrees with the observations of Lemosquet et al. (1997) and the lower intake of preformed LCFA. Reduced body fat mobilization, suggested by lower NEFA and increased ER with GG infusion, would also reduce the proportion of LCFA in milk fat (Hurtaud et al., 1998, 2000).

Nitrogen efficiency has been assessed at varying $\mathrm{CP}$ levels in response to altered energy levels incurred through changes in dietary NDF level (Broderick, 2003), supply of glucogenic energy from starch (Rius et al., 2010b; Cantalapiedra-Hijar et al., 2014), and postruminal glucose infusions (Clark et al., 1977). While we observed increased milk $\mathrm{N}$ efficiency in response to GG, this was driven by reduced $\mathrm{N}$ intake and not by increased milk $\mathrm{N}$ output, regardless of protein level of the infusion. We hypothesized that GG would stimulate milk protein yield at the LMP level by improving postabsorptive efficiency of $\mathrm{N}$ utilization through reduced splanchnic catabolism of AA, whereas at the HMP level GG would increase N retention. However, neither milk $\mathrm{N}$ output nor body $\mathrm{N}$ retention were affected by a $\mathrm{GG} \times \mathrm{AA}$ interaction. Nitrogen retention was negative on LMP-GG, but N intake decreased 112 $\mathrm{mg} / \mathrm{kg}$ of $\mathrm{BW}^{0.75}$ per $\mathrm{d}$ in response to $\mathrm{GG}$ and milk $\mathrm{N}$ was not affected. Low or negative $\mathrm{N}$ retention at the LMP level is not surprising considering only $75 \%$ of MP requirements were met. During GG infusion, mobilization of endogenous AA from body protein pools may have been necessary to maintain milk protein synthesis during reduced $\mathrm{N}$ intake at the LMP level.

It is often hypothesized that extra energy will partition AA toward milk protein synthesis (Clark et al., 1977; Raggio et al., 2006; Rius et al., 2010b), but our results with GG infusion do not support this hypothesis. When combined with infusions of casein or AA 
mixtures, glucose or glucose precursors stimulate milk protein yield in some studies (Raggio et al., 2006; Rius et al., 2010a), but not in all (Clark et al., 1977; Nichols et al., 2016). However, when circulating AA levels are abundant, exogenous glucose appears to have an effect on AA storage in extra-mammary tissues rather than on the stimulation of milk protein synthesis (Clark et al., 1977; Nichols et al., 2016; Curtis et al., 2018), possibly through the anabolic action of insulin on skeletal muscle (Lobley, 1998) and adipose (Griinari et al., 1997). In agreement with this hypothesis, $13 \%$ of $\mathrm{N}$ intake was retained on HMP-GG, compared with $6 \%$ on HMP-C, with no appreciable change in milk $\mathrm{N}$ output ( $1 \%$ of $\mathrm{N}$ intake) between treatments. It appears that at the LMP level, GG infusion may support milk protein synthesis by stimulating turnover in labile protein pools, whereas at the HMP level, GG infusion may partition excess AA back into those pools. In support of body $\mathrm{N}$ retention, the numerical decrease in urine $\mathrm{N}$ output in response to GG at the HMP level (between HMP-C and HMP-GG) is nearly 2 -fold the decrease at the LMP level (between LMP-C and LMP-GG), with no appreciable difference in fecal N output. Supplying GG at high MP levels apparently alters $\mathrm{N}$ utilization by lowering urinary $\mathrm{N}$ excretion, but does not partition extra $\mathrm{N}$ into milk. At a similar $\mathrm{N}$ intake as was achieved by our HMP level, Reynolds et al. (2001) also observed a decrease in urine $\mathrm{N}$, no change in milk $\mathrm{N}$, and an increase in tissue $\mathrm{N}$ retention with duodenal starch infusion compared with water.

The RQ was greater than 1.0 on all infusion treatments, likely resulting from the positive energy balance produced by the basal diet (Kuhla et al., 2015). De novo FA synthesis and ruminal anaerobic fermentation of dietary carbohydrates by ruminants can also result in a RQ larger than 1 (Gerrits et al., 2015). The increase in RQ in response to GG infusion agrees with the effect of GG on ER in body tissue, likely through adipogenesis.

Lipogenic Infusion. Infusion of palm olein decreased DMI $0.4 \mathrm{~kg} / \mathrm{d}$ compared with infusions with no LG. Feeding supplemental LCFA commonly results in no change or a hypophagic effect where DMI is affected less as the degree of FA saturation increases (Pantoja et al., 1996; Harvatine and Allen, 2006a), and this relationship appears to hold in studies where fat is infused postruminally (Drackley et al., 1992; Bremmer et al., 1998). The hypophagic response to FA absorption in the lower gut may be mediated by gut peptides (Relling and Reynolds, 2007). The decrease in DMI in our experiment is less severe compared with others infusing fat sources to mid-lactation cows in comparable doses and in FA profile similar to palm olein (Bremmer et al., 1998; Drackley et al., 2007). This is possibly due to the feed intake and energy restriction used in the current study, whereas others fed ad libitum and diets formulated to meet energy requirements. Importantly, GEI from the diet plus LG infusion was not affected, which supported the same total milk yield as LMP-C. Similar to GG, LG infusion increased the proportion of GEI recovered as $\mathrm{ME}$ and reduced $\mathrm{CH}_{4}$ production, but also tended to increase MEI.

Feeding lipogenic diets or infusing fat increases total milk yield in some studies (Cant et al., 1991; Nichols et al., 2018) but not in others (Oldick et al., 1997; Harvatine and Allen, 2006b; Lock et al., 2013). Although LG infusion did not improve milk yield, extra MEI contributed to $61 \mathrm{~kJ} / \mathrm{kg}$ of $\mathrm{BW}^{0.75}$ per $\mathrm{d}$ increase in milk energy output compared with non-LG infusion treatments, mainly by an increase in milk fat content, which agrees with our hypothesis. Improved transfer of energy from feed to milk with FA supplementation in mid-lactation has been observed by others (Andrew et al., 1991; Lock et al., 2013; Boerman et al., 2015), and MEI partitioned toward milk energy agrees with previous reports of lipogenic diets partitioning energy into milk instead of body fat compared with glucogenic diets (van Knegsel et al., 2007a; Boerman et al., 2015). Increases in plasma TAG and LCFA confirm absorption of infused LCFA in the lower gut and are in agreement with previous abomasal infusions of saturated LCFA (Drackley et al., 1992; Bremmer et al., 1998) and studies where rumen-inert fat is fed (Hammon et al., 2008; Boerman et al., 2015). No change in plasma NEFA with LG infusion agrees with findings of Bremmer et al. (1998) and Harvatine and Allen (2006b), and suggests TAG hydrolysis or peripheral tissue uptake of FA was not affected by LG infusion. Many have reported positive effects on milk fat yield and concentration when FA supply to the small intestine is increased by feeding rumen-inert fat sources (van Knegsel et al., 2007a; Lock et al., 2013; Nichols et al., 2018). Infusion of LG increased the concentrations of total preformed FA and total MUFA in milk fat, and decreased the concentrations of total de novo, mixed, and saturated FA, which agrees with the apparent transfer of $\mathrm{C} 18: 0$ and $\mathrm{C} 18: 1$ cis-9 from palm olein infusion. The increase in PUFA and n- 6 to n-3 ratio is supported by the transfer of C18: $2 \mathrm{n}-6$ from the infusion. Interestingly, C16:0 composed $43 \%$ of palm olein, but its concentration in milk fat decreased in response to LG, although the concentration of C16:0 in milk increased. Enjalbert et al. (2000) and Drackley et al. (2007) also reported increased milk C18:1 cis-9 content in milk fat at the expense of C16:0 during oleic acid infusion. This effect may be related to inhibition of de novo synthesis of $\leq 16 \mathrm{C}$ FA by $\mathrm{C} 18: 1$ cis-9 through displacement of $14: 0$ and $16: 0$ by C18:1 at the $s n-2$ position of glycerol (Hansen and Knudsen, 
1987; Loften et al., 2014). In addition, Enjalbert et al. (2000) reported high intestinal digestibility of C18:1 cis-9, but increased C16:0 content in feces during oleic acid infusion. Although we observed no effect of LG on manure energy output, if digestibility of C18:1 in the infusion was high and C16:0 digestibility was low, this could contribute to the decreased concentration of C16:0 in milk fat.

We hypothesized that LG would improve milk N efficiency at the LMP and at the HMP level. However, although $\mathrm{N}$ intake decreased with LG infusion, LG did not affect milk $\mathrm{N}$ efficiency, plasma urea concentration, or any other parameters related to $\mathrm{N}$ balance. Andrew et al. (1991) and Cant et al. (1991) observed no difference in transfer efficiency of $\mathrm{N}$ intake into milk $\mathrm{N}$ when dietary fat was supplemented at high or low dietary CP protein levels or during AA infusions, respectively. In contrast, Nichols et al. (2018) report increased milk protein yield and increased milk $\mathrm{N}$ efficiency when saturated fat was supplemented to low- or high-protein diets achieved through rumen-protected protein supplementation. However, Nichols et al. (2018) reported a tendency for interaction between fat and protein supplementation on milk $\mathrm{N}$ efficiency, where the addition of fat numerically increased milk $\mathrm{N}$ efficiency to a larger extent at low protein level than at high protein level. In the present experiment, the same numerical trend occurred. At the LMP level, LG increased milk N efficiency $1.8 \%$ units, whereas at the HMP level LG produced the same milk $\mathrm{N}$ efficiency as HMP-C. Nitrogen intake decreased with LG, but $\mathrm{N}$ retention at the HMP level was numerically higher than at the LMP level. This may account for the numerically identical milk $\mathrm{N}$ efficiency between HMPLG and HMP-C, despite lower $\mathrm{N}$ intake with LG. In contrast with the comparison between Nichols et al. (2018) (saturated fat) and the current work (mixture of saturated and monounsaturated fat), Bremmer et al. (1998) saw no difference in dietary CP intake or $\mathrm{N}$ components of milk between infusion of saturated LCFA and palm oil. The relationship between degree of saturation of postruminal FA supplements and milk $\mathrm{N}$ efficiency, with and without AA supplementation, remains poorly characterized.

The RQ decreased in response to LG infusion. van Gastelen et al. (2017) observed a similar RQ of 1.10 when dairy cow diets were supplemented with linseed oil. Lower RQ during LG infusion, relative to infusions with no LG, suggests increased FA absorption and reduced FA synthesis during intermediary metabolism (Gerrits et al., 2015).

Protein Level. Effects of GG and LG proved to be largely independent of MP level in the current study. Similarly, the HMP level influenced energy and $\mathrm{N}$ partitioning independent of GG or LG due to the stimulation of DMI and increased $\mathrm{N}$ supply. The effect on DMI detected in the present study in response to AA might more strongly reflect the decrease in DMI when energy was added at the LMP level from GG or LG, because when the same amount of energy was provided with HMP-C, DMI was not numerically different from LMP-C. At the HMP level, DMI increased $0.1 \mathrm{~kg} / \mathrm{d}$ without GG or $\mathrm{LG}$ and $0.9 \mathrm{~kg} / \mathrm{d}$ with $\mathrm{GG}$ or LG. Because diet DMI increased at the HMP level, GEI increased $182 \mathrm{~kJ} / \mathrm{kg}$ of $\mathrm{BW}^{0.75}$ per d on HMP-C compared with LMP-GG and LMP-LG, even though the infusions were isoenergetic. Gross energy intake was formulated to be highest on HMP-GG and HMP-LG because of the additive infusion doses of GG or LG and AA, which was achieved regardless of the independent effects of GG, LG, and AA on DMI.

Methane production increased at the HMP level from the increased DMI (Ellis et al., 2008), and the proportion of GEI recovered as MEI increased. Greater $\mathrm{N}$ supply at the HMP level did not affect total ER, but heat production increased only when GG or LG were added to the HMP level. A portion of this increase in heat production is attributed to rumen microbial fermentation and $\mathrm{O}_{2}$ consumption by the portal-drained viscera and liver, related to greater DMI (Reynolds, 2002; Russell and Strobel, 2005). Supplying N in excess of requirement also produces heat during biological transformations of $\mathrm{N}$ molecules, such as AA oxidation, urea synthesis, and $\mathrm{N}$ recycling, before excretion (Reed et al., 2017). The form of dietary $\mathrm{N}$ affects the amount of energy required for its oxidative metabolism, which was found to be lower with RUP than with RDP per unit supplied (Reed et al., 2017). The increase in N intake between the LMP and HMP level represents an increase in essentially completely RUP (average increase of $13 \mathrm{~g}$ of $\mathrm{N} / \mathrm{d}$ from the diet, which reflects a mixture of RDP and RUP, compared with $122 \mathrm{~g}$ of N/d from AA infusion, which is considered RUP). From estimations of Reed et al. (2017) that 3.3 MJ of heat is produced per $\mathrm{kg}$ of RUP, the HMP level produced $23 \mathrm{~kJ} / \mathrm{kg}$ of $\mathrm{BW}^{0.75}$ per $\mathrm{d}$ of heat from EAA infusion. Of the increase in heat production, $32 \%$ could have been achieved by metabolism of infused EAA. Taken together, this suggests the observed increase in heat production when AA is supplied together with GG or LG may have been more related to the overall increase in MEI at the HMP level than to increased catabolism of infused EAA. Lack of effect of AA on total ER agrees with Reed et al. (2017) but contrasts earlier suggestions that casein infusions stimulate milk production in part by releasing energy from adipose tissue stores (Ørskov et al., 1977; Whitelaw et al., 1986). In these studies where negative ER was observed, animals were in an earlier stage of lactation and total GEI was lower 
than in our study. In common with other reports of postruminal AA supplementation (Clark et al., 1977; Whitelaw et al., 1986; Wright et al., 1998), the HMP level increased milk $\mathrm{N}$ output, tended to increase $\mathrm{N}$ retention, increased plasma urea concentration, and decreased milk $\mathrm{N}$ efficiency. The $\mathrm{N}$ retention values reported here are in line with others who supply similar levels of postruminal AA to mid-lactation cows (Clark et al., 1977; Wright et al., 1998; Castillo et al., 2001). In general, milk urea concentration may serve as an on-farm indicator to monitor environmental $\mathrm{N}$ emission and milk $\mathrm{N}$ efficiency, but the relationship between milk urea and $\mathrm{N}$ excretion is variable (reviewed by Spek et al., 2013b). In our experiment, the decrease in milk $\mathrm{N}$ efficiency upon infusing EAA was reflected in increased milk urea levels, and milk $\mathrm{N}$ efficiency as well as milk urea were not affected by LG infusion. However, the improvement in milk $\mathrm{N}$ efficiency upon GG infusion independent of protein level did not coincide with lower milk urea levels, indicating that milk urea concentration is not necessarily a sound indicator of milk $\mathrm{N}$ efficiency.

Milk energy output increased at the HMP level, which agrees with the increased yield of milk fat, protein, and lactose when EAA were infused. The contribution of increased DMI to LCFA intake remained small $(19 \mathrm{~g} / \mathrm{d}$ increase in crude fat intake), suggesting intramammary FA synthesis supported the $71 \mathrm{~g} / \mathrm{d}$ increase in milk fat yield stimulated by the HMP level. In agreement with intramammary FA synthesis, concentration of de novo FA in milk increased, and total $16 \mathrm{C}$ FA concentration decreased. Infusions of casein or AA mixtures usually increase milk protein but also lactose yield (Doepel and Lapierre, 2010; Galindo et al., 2011; Nichols et al., 2016), likely through the effects of AA on whole-body glucose appearance, or through changes in mammary synthetic capacity associated with the stimulatory effect of AA on milk protein synthesis (Lemosquet et al., 2009; Lapierre et al., 2010). Interestingly, lactose content decreased at the HMP level. Depressed lactose content when mammary AA supply is high could be in response to the positive relationship between milk salt and milk casein content (Bijl et al., 2013) and mechanistically linked to the requirement to maintain milk osmolality when AA flux through $\mathrm{Na}^{+}$-dependent transporters is elevated. An inverse relationship exists between milk lactose concentration and that of $\mathrm{Na}$ and K (Peaker, 1983), related to intracellular osmotic pressure, which equilibrates between milk and milk secretory cells in the udder (Shennan and Peaker, 2000). Under conditions of increased AA flux into mammary cells via $\mathrm{Na}^{+}$-dependent transporters, $\mathrm{Na}^{+} / \mathrm{K}^{+}$ATPase activity may be upregulated to balance intracellular $\mathrm{Na}^{+}$concentration and facilitate AA influx (McGivan and Pastor-Anglada, 1994). Increased intracellular $\mathrm{K}^{+}$ concentration may thereby result in reduced lactose content to maintain constant osmotic pressure of milk.

The RQ decreased at the HMP level, which suggests AA were used for energy generation when EAA were infused, and agrees with increased AA catabolism observed in response to high levels of protein supply (Doepel et al., 2004; Lapierre et al., 2006). The average RQ at the HMP level of 1.11 is in line with the value of 1.08 reported by Whitelaw et al. (1986).

\section{Digestibility}

Minimal effects on ATTD of DM, OM, and NDF indicates that abomasal infusion of glucose, palm olein, or EAA did not disrupt normal digestive processes in the current study. Decreased ATTD of crude fat in response to GG can be attributed to the reduction in DMI and therefore crude fat intake, resulting in a relatively higher contribution of endogenous fat losses to fecal fat excretion (Kil et al., 2010). In response to LG, ATTD of crude fat increased more than expected based upon an assumed $80 \%$ digestibility of palm olein. Assuming crude fat digestibility on LMP-C represents the crude fat digestibility of the basal diet, and that this remains constant, the increase in fat digestibility with LG infusion suggests that digestibility of palm olein may have been higher (84-85\%). Indeed, Drackley et al. (2007) and others (Bremmer et al., 1998; Enjalbert et al., 2000) have observed high intestinal digestibility of total LCFA, specifically oleic acid, reaching the small intestine during abomasal infusion of LCFA. Because almost half of palm olein is oleic acid, this could account for the high calculated apparent digestibility of infused fat. However, GE digestibility was not affected by LG, which would be expected if the digestibility of infused fat had an appreciable effect considering the high GE content of palm olein. The HMP level increased ATTD of DM (tendency only) and GE, which can be explained by the greater assumed digestibility of infused EAA (100\%) compared with basal diet digestibility, as these effects disappeared when ATTD was calculated considering only inflows from the basal diet (data not shown). Similarly, increased ATTD of CP at the HMP level can be attributed to high digestibility of the EAA infusion, which was also observed by Wright et al. (1998) when a highly digestible RUP source replaced a portion of their basal diet.

\section{CONCLUSIONS}

This study demonstrates that postruminal glucose and palm olein supported milk production and stimulated alterations in whole-body energy and $\mathrm{N}$ partitioning which were largely independent of protein-level. 
Glucose infusion promoted total body ER, reduced milk energy output, and improved milk $\mathrm{N}$ efficiency. Palm olein infusion partitioned extra energy intake toward milk fat production at the same level of total milk and protein production, and had no effect on milk $\mathrm{N}$ efficiency. Infusing EAA increased milk fat, protein, and lactose production without negatively affecting energy balance, but decreased milk N efficiency. Heat production increased at the high MP level, but only at the additive energy level where glucose or palm olein were infused with EAA. With regard to energy balance, palm olein allowed greater milk energy without affecting ER, whereas glucose promoted ER at low and high MP levels. Glucose infusion increased milk N efficiency at low and high MP levels but did not produce extra milk protein yield. The efficacy of lipogenic substrate on milk $\mathrm{N}$ efficiency should be further elucidated.

\section{ACKNOWLEDGMENTS}

The authors gratefully acknowledge technical assistance from Sven Alferink, Marcel Heetkamp, Tamme Zandstra, and the animal caretakers of the experimental facilities of "Carus" (Wageningen University and Research, Wageningen, the Netherlands), and from Inge van Bakel and Koen van Helvoort (students of Wageningen University, Wageningen, the Netherlands). Gas chromatography was performed at RIKILT (Wageningen University and Research, Wageningen, the Netherlands) with the assistance of Rita BoerrigterEenling. This research was conducted by Wageningen University and Research (Wageningen Livestock Research, Wageningen, the Netherlands), commissioned and funded by the Ministry of Agriculture, Nature and Food Quality (The Hague, the Netherlands) within the framework of Policy Support Research theme "Feed4Foodure" (BO-31.03-005-001; TKI-AF12039B), and by the Vereniging Diervoederonderzoek Nederland (Rijswijk, the Netherlands).

\section{REFERENCES}

Adewuyi, A. A., E. Gruys, and F. J. C. M. van Eerdenburg. 2005. Non esterified fatty acids (NEFA) in dairy cattle. A review. Vet. Q. 27:117-126.

Andrew, S. M., H. F. Tyrrell, C. K. Reynolds, and R. A. Erdman. 1991. Net energy for lactation of calcium salts of long-chain fatty acids for cows fed silage-based diets. J. Dairy Sci. 74:2588-2600.

Arriola Apelo, S. I., A. L. Bell, K. Estes, J. Ropelewski, M. J. de Veth, and M. D. Hanigan. 2014. Effects of reduced dietary protein and supplemental rumen-protected essential amino acids on the nitrogen efficiency of dairy cows. J. Dairy Sci. 97:5688-5699.

Baird, G. D., M. A. Lomax, H. W. Symonds, and S. R. Shaw. 1980. Net hepatic and splanchnic metabolism of lactate, pyruvate and propionate in dairy cows in vivo in relation to lactation and nutrient supply. Biochem. J. 186:47-57.
Bauman, D. E., and J. M. Elliot. 1983. Control of nutrient partitioning in lactating ruminants. Page 437 in Biochemistry of Lactation. T. B. Mepham, ed. Elsevier Sci. Publ. B.V., Amsterdam, the Netherlands.

Benson, J. A., C. K. Reynolds, D. J. Humphries, S. M. Rutter, and D. E. Beever. 2001. Effects of abomasal infusion of long-chain fatty acids on intake, feeding behavior and milk production in dairy cows. J. Dairy Sci. 84:1182-1191.

Bijl, E., H. J. van Valenberg, T. Huppertz, and A. C. van Hooijdonk 2013. Protein, casein, and micellar salts in milk: Current content and historical perspectives. J. Dairy Sci. 96:5455-5464.

Boerman, J. P., S. B. Potts, M. J. VandeHaar, and A. L. Lock. 2015. Effects of partly replacing dietary starch with fiber and fat on milk production and energy partitioning. J. Dairy Sci. 98:7264-7276.

Bremmer, D. R., L. D. Ruppert, J. H. Clark, and J. K. Drackley. 1998 Effects of chain length and unsaturation of fatty acid mixtures infused into the abomasum of lactating dairy cows. J. Dairy Sci. $81: 176-188$

Broderick, G. A. 2003. Effects of varying dietary protein and energy levels on the production of lactating dairy cows. J. Dairy Sci. 86:1370-1381

Cant, J. P., E. J. DePeters, and R. L. Baldwin. 1991. Effect of dietary fat and postruminal casein administration on milk composition of lactating dairy cows. J. Dairy Sci. 74:211-219.

Cantalapiedra-Hijar, G., J. L. Peyraud, S. Lemosquet, E. Molina-Alcaide, H. Boudra, P. Nozière, and I. Ortigues-Marty. 2014. Dietary carbohydrate composition modifies the milk $\mathrm{N}$ efficiency in late lactation cows fed low crude protein diets. Animal 8:275-285.

Castillo, A. R., E. Kebreab, D. E. Beever, J. H. Barbi, J. D. Sutton, H. C. Kirby, and J. France. 2001. The effect of protein supplementation on nitrogen utilization in lactating dairy cows fed grass silage diets. J. Anim. Sci. 79:247-253.

Clark, J. H., H. R. Spires, R. G. Derrig, and M. R. Bennink. 1977. Milk production, nitrogen utilization and glucose synthesis in lactating cows infused postruminally with sodium caseinate and glucose. J. Nutr. 107:631-644.

Curtis, R. V., J. J. M. Kim, J. Doelman, and J. P. Cant. 2018. Maintenance of plasma branched-chain amino acid concentrations during glucose infusion directs essential amino acids to extra- mammary tissues in lactating dairy cows. J. Dairy Sci. 101:4542-4553.

CVB (Centraal Veevoederbureau). 2008. CVB Table Ruminants 2008, series nr. 43. CVB, The Hague, The Netherlands.

Dijkstra, J., C. K. Reynolds, E. Kebreab, A. Bannink, J. L. Ellis, J. France, and A. M. van Vuuren. 2013. Challenges in ruminant nutrition: Towards minimal nitrogen losses in cattle. Pages 47-58 in Energy and Protein Metabolism and Nutrition in Sustainable Animal Production. W. J. Oltjen, E. Kebreab, and H. Lapierre, ed. Wageningen Academic Publishers, Wageningen, the Netherlands.

Doepel, L., and H. Lapierre. 2010. Changes in production and mammary metabolism of dairy cows in response to essential and nonessential amino acid infusions. J. Dairy Sci. 93:3264-3274.

Doepel, L., D. Pacheco, J. J. Kennelly, M. D. Hanigan, I. F. López, and H. Lapierre. 2004. Milk protein synthesis as a function of amino acid supply. J. Dairy Sci. 87:1279-1297.

Drackley, J. K., T. H. Klusmeyer, A. M. Trusk, and J. H. Clark. 1992. Infusion of long-chain fatty acids varying in saturation and chain length into the abomasum of lactating dairy cows. J. Dairy Sci. $75: 1517-1526$.

Drackley, J. K., T. R. Overton, G. Ortiz-Gonzalez, A. D. Beaulieu, D. M. Barbano, J. M. Lynch, and E. G. Perkins. 2007. Responses to increasing amounts of high-oleic sunflower fatty acids infused into the abomasum of lactating dairy cows. J. Dairy Sci. 90:5165-5175.

Ellis, J. L., J. Dijkstra, E. Kebreab, A. Bannink, N. E. Ondongo, B. W. McBride, and J. France. 2008. Aspects of rumen microbiology central to mechanistic modelling of methane production in cattle. J. Agric. Sci. 146:213-233.

Enjalbert, F., M. C. Nicot, C. Bayourthe, and R. Moncoulon. 2000. Effects of duodenal infusions of palmitic, stearic, or oleic acids on milk composition and physical properties of butter. J. Dairy Sci. $83: 1428-1433$ 
European Commission. 2010. Directive 2010/63/EU of the European Parliament and of the council of 22 September 2010 on the protection of animals used for scientific purposes. Accessed Oct. 12, 2018. http://eur-lex.europa.eu/LexUriServ/LexUriServ.do?uri= OJ:L:2010:276:0033:0079:eN:PDF.

Galindo, C. E., D. R. Ouellet, D. Pellerin, S. Lemosquet, I. OrtiguesMarty, and H. Lapierre. 2011. Effect of amino acid or casein supply on whole-body, splanchnic, and mammary glucose kinetics in lactating dairy cows. J. Dairy Sci. 94:5558-5568.

Gerrits, W. J. J., J. J. G. C. van den Borne, and E. Labussière. 2015. Deriving heat production from gaseous exchange: validity of the approach. Pages 19-34 in Indirect Calorimetry. Techniques, Computations and Applications. W. J. J. Gerrits and E. Labussière, ed. Wageningen Academic Publishers, Wageningen, the Netherlands.

Griinari, J. M., M. A. McGuire, D. A. Dwyer, D. E. Bauman, and D. L. Palmquist. 1997. Role of insulin in the regulation of milk fat synthesis in dairy cows. J. Dairy Sci. 80:1076-1084.

Hammon, H. M., C. C. Metges, P. Junghans, F. Becker, O. Bellmann, F. Schnieder, G. Nürnberg, P. Dubreuil, and H. Lapierre. 2008. Metabolic changes and net portal flux in dairy cows fed a ration containing rumen-protected fat as compared to a control diet. J. Dairy Sci. 91:208-217.

Hansen, H. O., and J. Knudsen. 1987. Effect of exogenous long-chain fatty acids on individual fatty acid synthesis by dispersed ruminant mammary gland cells. J. Dairy Sci. 70:1350-1354.

Haque, M. N., H. Rulquin, A. Andrade, P. Faverdin, J. L. Peyraud, and S. Lemosquet. 2012. Milk protein synthesis in response to the provision of an "ideal" amino acid profile at 2 levels of metabolizable protein supply in dairy cows. J. Dairy Sci. 95:5876-5887.

Harvatine, K. J., and M. S. Allen. 2006a. Effects of fatty acid supplements on feed intake, and feeding and chewing behavior of lactating dairy cows. J. Dairy Sci. 89:1104-1112.

Harvatine, K. J., and M. S. Allen. 2006b. Effects of fatty acid supplements on milk yield and energy balance of lactating dairy cows. J. Dairy Sci. 89:1081-1091.

Heetkamp, M. J. W., S. J. J. Alferink, T. Zandstra, P. Hendriks, H. van den Brand, and W. J. J. Gerrits. 2015. Design of climate respiration chambers, adjustable to the metabolic mass of subjects. Pages 35-56 in Indirect Calorimetry. Techniques, Computations and Applications. W. J. J. Gerrits and E. Labussière, ed. Wageningen Academic Publishers, Wageningen, the Netherlands.

Hurtaud, C., S. Lemosquet, and H. Rulquin. 2000. Effect of graded duodenal infusions of glucose on yield and composition of milk from dairy cows. 2. Diets based on grass silage. J. Dairy Sci. 83:2952-2962.

Hurtaud, C., H. Rulquin, and R. Verite. 1998. Effects of graded duodenal infusions of glucose on yield and composition of milk from dairy cows. 1. Diets based on corn silage. J. Dairy Sci. 81:3239-3247.

ISO. 1998. Animal feeding stuffs, animal products, and feces or urine. Determination of gross calorific value-Bomb calorimeter method. International Standards Organization, Geneva, Switzerland.

ISO. 2013. Milk and liquid milk products. Guidelines for the application of mid-infrared spectrometry. International Standards Organization, Geneva, Switzerland.

Kil, D. Y., T. E. Sauber, D. B. Jones, and H. H. Stein. 2010. Effect of the form of dietary fat and the concentration of dietary neutral detergent fiber on ileal and total tract endogenous losses and apparent and true digestibility of fat by growing pigs. J. Anim. Sci. 88:2959-2967.

Kuhla, B., M. Derno, and C. C. Metges. 2015. Indirect calorimetry for elucidating dynamics in energy metabolism of farm animals. Pages 115-133 in Indirect Calorimetry. Techniques, Computations and Applications. W. J. J. Gerrits and E. Labussière, ed. Wageningen Academic Publishers, Wageningen, the Netherlands.

Lapierre, H., C. E. Galindo, S. Lemosquet, I. Ortigues-Marty, L. Doepel, and D. R. Ouellet. 2010. Protein supply, glucose kinetics and milk yield in dairy cows. Pages $275-285$ in EAAP publication No. 127. Wageningen Academic Publishers, the Netherlands.

Lapierre, H., D. Pacheco, R. Berthiaume, D. R. Ouellet, C. G. Schwab, P. Dubreuil, G. Holtrop, and G. E. Lobley. 2006. What is the true supply of amino acids for a dairy cow? J. Dairy Sci. 89 (E. Suppl.):E1-E14.

Lemosquet, S., G. Raggio, G. E. Lobley, H. Rulquin, J. Guinard-Flament, and H. Lapierre. 2009. Whole-body glucose metabolism and mammary energetic nutrient metabolism in lactating dairy cows receiving digestive infusions of casein and propionic acid. J. Dairy Sci. 92:6068-6082.

Lemosquet, S., N. Rideau, H. Rulquin, P. Faverdin, J. Simon, and R. Verite. 1997. Effects of a duodenal glucose infusion on the relationship between plasma concentrations of glucose and insulin in dairy cows. J. Dairy Sci. 80:2854-2865.

Lobley, G. E. 1998. Nutritional and hormonal control of muscle and peripheral tissue metabolism in farm species. Livest. Prod. Sci. 56:91-114.

Lock, A. L., C. L. Preseault, J. E. Rico, K. E. DeLand, and M. S. Allen. 2013. Feeding a C16:0-enriched fat supplement increased the yield of milk fat and improved conversion of feed to milk. J. Dairy Sci. 96:6650-6659.

Loften, J. R., J. G. Linn, J. K. Drackley, T. C. Jenkins, C. G. Soderholm, and A. F. Kertz. 2014. Invited review: Palmitic and stearic acid metabolism in lactating dairy cows. J. Dairy Sci. 97:46614674 .

Lohrenz, A.-K., K. Duske, F. Schneider, K. Nürnberg, B. Losand, H. M. Seyfert, C. C. Metges, and H. Hammon. 2010. Milk performance and glucose metabolism in dairy cows fed rumen-protected fat during mid lactation. J. Dairy Sci. 93:5867-5876.

Lomax, M. A., G. D. Baird, C. B. Mallinson, and H. W. Symonds, 1979. Differences between lactating and non-lactating dairy cows in concentration and secretion rate of insulin. Biochem. J. 180:281-289.

Martin, A. K., and K. L. Blaxter. 1965. The energy cost of urea synthesis in sheep. Pages 83-91 in Proceedings of the 3rd Symposium on Energy Metabolism. K. L. Blaxter, ed. Academic Press, London, UK.

McGivan, J. D., and M. Pastor-Anglada. 1994. Regulatory and molecular aspects of mammalian amino acid transport. Biochem. J. 299:321-334.

McGuire, M. A., J. M. Griinari, D. A. Dwyer, and D. E. Bauman. 1995. Role of insulin in the regulation of mammary synthesis of fat and protein. J. Dairy Sci. 78:816-824.

Metcalf, J. A., L. A. Crompton, D. Wray-Cahen, M. A. Lomax, J. D. Sutton, D. E. Beever, J. C. MacRae, B. J. Bequette, F. R. C. Backwell, and G. E. Lobley. 1996. Responses in milk constituents to intravascular administration of two mixtures of amino acids to dairy cows. J. Dairy Sci. 79:1425-1429.

Nichols, K., A. Bannink, S. Pacheco, H. J. van Valenberg, J. Dijkstra, and H. van Laar. 2018. Feed and nitrogen efficiency are affected differently but milk lactose production is stimulated equally when isoenergetic protein and fat is supplemented in lactating dairy cow diets. J. Dairy Sci. 101:7857-7870.

Nichols, K., J. J. M. Kim, M. Carson, J. A. Metcalf, J. P. Cant, and J. Doelman. 2016. Glucose supplementation stimulates peripheral branched-chain amino acid catabolism in lactating dairy cows during essential amino acid infusions. J. Dairy Sci. 99:1145-1160.

NRC. 2001. Nutrient Requirements of Dairy Cattle. 7th rev. ed. Natl. Acad. Sci., Washington, DC.

O'Connor, P. M., S. R. Kimball, A. Suryawan, J. A. Bush, H. V. Hguyen, L. S. Jefferson, and T. A. Davis. 2003. Regulation of translation initiation by insulin and amino acids in skeletal muscle of neonatal pigs. Am. J. Physiol. Endocrinol. Metab. 285:E40-E53.

Oldick, B. S., C. R. Staples, W. W. Thatcher, and P. Gyawu. 1997. Abomasal infusion of glucose and fat - effects on digestion, production, and ovarian and uterine functions of cows. J. Dairy Sci. 80:1315-1328.

Ørskov, E. R., D. A. Grubb, and R. N. B. Kay. 1977. Effect of postruminal glucose or protein supplementation on milk yield and composition in Friesian cows in early lactation and negative energy balance. Br. J. Nutr. 38:397-405.

Pantoja, J., J. L. Firkins, and M. L. Eastridge. 1996. Fatty acid digestibility and lactation performance by dairy cows fed fats varying in degree of saturation. J. Dairy Sci. 79:429-437. 
Peaker, M. 1983. Secretion of ions and water. Pages 285-305 in Biochemistry of Lactation. T. B. Mepham, ed. Elsevier, Amsterdam, the Netherlands.

Raggio, G., G. E. Lobley, S. Lemosquet, H. Rulquin, and H. Lapierre. 2006. Effect of casein and propionate supply on whole body protein metabolism in lactating dairy cows. Can. J. Anim. Sci. $86: 81-89$.

Reed, K. F., H. C. Bonfá, J. Dijkstra, D. P. Casper, and E. Kebreab. 2017. Estimating the energetic cost of feeding excess dietary nitrogen to dairy cows. J. Dairy Sci. 100:7116-7126.

Relling, A. E., and C. K. Reynolds. 2007. Feeding rumen-inert fats differing in their degree of saturation decreases intake and increases plasma concentrations of gut peptides in lactating dairy cows. J. Dairy Sci. 90:1506-1515.

Reynolds, C. K. 2002. Economics of visceral energy metabolism in ruminants: Toll keeping or internal revenue service?. J. Anim. Sci. 80(E. Suppl. 2):E74-E84.

Reynolds, C. K., S. B. Cammell, D. J. Humphries, D. E. Beever, J. D. Sutton, and J. R. Newbold. 2001. Effects of postrumen starch infusion on milk production and energy metabolism in dairy cows. J. Dairy Sci. 84:2250-2259.

Rigout, S., S. Lemosquet, A. Bach, J. W. Blum, and H. Rulquin. 2002a. Duodenal infusion of glucose decreases milk fat production in grass silage-fed dairy cows. J. Dairy Sci. 85:2541-2550.

Rigout, S., S. Lemosquet, J. E. van Eys, J. W. Blum, and H. Rulquin. 2002b. Duodenal glucose increases fluxes and lactose synthesis in grass silage-fed dairy cows. J. Dairy Sci. 85:595-606.

Rius, A. G., J. A. D. R. N. Appuhamy, J. Cyriac, D. Kirovski, O. Becvar, J. Escobar, M. L. McGilliard, B. J. Bequette, R. M. Akers, and M. D. Hanigan. 2010a. Regulation of protein synthesis in mammary glands of lactating dairy cows by starch and amino acids. J. Dairy Sci. 93:3114-3127.

Rius, A. G., M. L. McGilliard, C. A. Umberger, and M. D. Hanigan. 2010b. Interactions of energy and predicted metabolizable protein in determining nitrogen efficiency in the lactating dairy cow. J. Dairy Sci. 93:2034-2043.

Russell, J. B., and H. J. Strobel. 2005. Microbial energetics. Pages 229-261 in Quantitative Aspects of Ruminant Digestion and Metabolism, 2nd Ed. J. Dijkstra, J. M. Forbes, and J. France, ed. CABI Publishing, Cambridge, MA.

Shennan, D. B., and M. Peaker. 2000. Transport of milk constituents by the mammary gland. Physiol. Rev. 80:925-951.

Spek, J. W., J. Dijkstra, G. van Duinkerken, and A. Bannink. 2013b. A review of factors influencing milk urea concentration and its relationship with urinary urea excretion in lactating dairy cattle. J. Agric. Sci. 151:407-423.

Spek, J. W., J. Dijkstra, G. van Duinkerken, W. H. Hendriks, and A. Bannink. 2013a. Prediction of urinary nitrogen and urinary urea nitrogen excretion by lactating dairy cattle in northwestern Europe and North America: A meta-analysis. J. Dairy Sci. 96:4310-4322.

Van Es, A. J. H. 1978. Feed evaluation for ruminants. I. The systems in use from May 1977-onwards in The Netherlands. Livest. Prod. Sci. 5:331-345.

van Gastelen, S., E. C. Antunes-Fernandes, K. A. Hettinga, G. Klop, S. J. J. Alferink, W. H. Hendriks, and J. Dijkstra. 2015. Enteric methane production, rumen volatile fatty acid concentrations, and milk fatty acid composition in lactating Holstein-Friesian cows fed grass silage- or corn silage-based diets. J. Dairy Sci. 98:1915-1927.

van Gastelen, S., M. H. P. W. Visker, J. E. Edwards, E. C. AntunesFernandes, K. A. Hettinga, S. J. J. Alferink, W. H. Hendriks, H. Bovenhuis, H. Smidt, and J. Dijkstra. 2017. Linseed oil and DGAT1 K232A polymorphism: effects on methane emission, energy and $\mathrm{N}$ metabolism, lactation performance, ruminal fermentation, and rumen-microbial composition of Holstein-Friesian cows. J. Dairy Sci. 100:8939-8957.

van Knegsel, A. T. M., H. van den Brand, J. Dijkstra, W. M. van Straalen, M. J. W. Heetkamp, S. Tamminga, and B. Kemp. 2007a. Dietary energy source in dairy cows in early lactation: Energy partitioning and milk composition. J. Dairy Sci. 90:1467-1476.

van Knegsel, A. T. M., H. van den Brand, J. Dijkstra, W. M. van Straalen, R. Jorritsma, S. Tamminga, and B. Kemp. 2007b. Effect of glucogenic vs. lipogenic diets on energy balance, blood metabolites, and reproduction in primiparous and multiparous dairy cows in early lactation. J. Dairy Sci. 90:3397-3409.

Whitelaw, F. G., J. S. Milne, E. R. Ørskov, and J. S. Smith. 1986. The nitrogen and energy metabolism of lactating cows given abomasal infusions of casein. Br. J. Nutr. 55:537-556.

Williams, E. J. 1949. Experimental designs balanced for the estimation of residual effects of treatments. Aust. J. Sci. Res., A 2:149-168.

Wilson, F. A., A. Suryawan, M. C. Gazzaneo, R. A. Orellana, H. V. Nguyen, and T. A. Davis. 2010. Stimulation of muscle protein synthesis by prolonged parenteral infusion of leucine is dependent on amino acid availability in neonatal pigs. J. Nutr. 140:264-270.

Wright, T. C., S. Moscardini, P. H. Luimes, P. Susmel, and B. W. McBride. 1998. Effects of rumen-undegradable protein and feed intake on nitrogen balance and milk production in dairy cows. J. Dairy Sci. 81:784-793. 